\title{
Renewed methane increase for five years (2007-2011) observed by solar FTIR spectrometry
}

\author{
R. Sussmann ${ }^{1}$, F. Forster ${ }^{1}$, M. Rettinger ${ }^{1}$, and P. Bousquet ${ }^{2,3}$ \\ ${ }^{1}$ Karlsruhe Institute of Technology, IMK-IFU, Garmisch-Partenkirchen, Germany \\ ${ }^{2}$ Laboratoire des Sciences du Climat et de l'Environnement, IPSL-LSCE, CEA-CNRS-UVSQ, UMR8212 91191, France \\ ${ }^{3}$ Université de Versailles Saint Quentin en Yvelines, France
}

Correspondence to: R. Sussmann (ralf.sussmann@kit.edu)

Received: 11 October 2011 - Published in Atmos. Chem. Phys. Discuss.: 16 November 2011

Revised: 16 May 2012 - Accepted: 21 May 2012 - Published: 4 June 2012

Abstract. Trends of column-averaged methane for the time period (1996, Sep 2011) are derived from the mid-infrared (mid-IR) solar FTIR time series at the Zugspitze $\left(47.42^{\circ} \mathrm{N}\right.$, $10.98^{\circ} \mathrm{E}, 2964 \mathrm{~m}$ a.s.l. $)$ and Garmisch $\left(47.48^{\circ} \mathrm{N}, 11.06^{\circ} \mathrm{E}\right.$, $743 \mathrm{~m}$ a.s.1.). Trend analysis comprises a fit to the deseasonalized time series along with bootstrap resampling for quantifying trend uncertainties. We find a positive trend during [1996, 1998] of $9.0[3.2,14.7] \mathrm{ppb} \mathrm{yr}^{-1}$ for Zugspitze (95\% confidence interval), an insignificant growth during [1999, mid 2006] of $0.8[-0.1,1.7] \mathrm{ppb} \mathrm{yr}^{-1}$ (Zugspitze), and a significant renewed increase during [mid 2006, Sep 2011] of $5.1[4.2,6.0] \mathrm{ppb} \mathrm{yr}^{-1}$ for Garmisch, which is in agreement with $4.8[3.8,5.9] \mathrm{ppb} \mathrm{yr}^{-1}$ for Zugspitze.

The agreement of methane trends at the two closely neighboring FTIR sites Zugspitze and Garmisch within the uncertainties indicates a good station-to-station consistency as a basis for future trend analyses by the ground-based midIR FTIR network on the global scale. Furthermore, the Zugspitze FTIR trend for the time interval [Jul 2006, Jun 2009] is found to agree with the trend derived from SCIAMACHY (WFM-DOAS v2.0.2) data within the 95\% confidence intervals. In case a $1000-\mathrm{km}$ pixel selection radius around the Zugspitze is used, the confidence interval is narrower for the FTIR trend $\left(6.9[4.2,9.5] \mathrm{ppb} \mathrm{yr}^{-1}\right)$ compared to SCIAMACHY $\left(7.1[5.1,8.6] \mathrm{ppb} \mathrm{yr}^{-1}\right)$. If, however, a loosened pixel selection is used $(\approx 1000$-km half-width latitudinal band), the SCIAMACHY trend significance interval is narrower $\left(6.8[5.1,8.6] \mathrm{ppb} \mathrm{yr}^{-1}\right)$ compared to Zugspitze FTIR (5.7 [3.0, 8.3] $\left.\mathrm{ppb} \mathrm{yr}^{-1}\right)$.

While earlier studies using surface network data revealed changes of $8.0 \pm 0.6 \mathrm{ppb}$ in $2007,6.4 \pm 0.6 \mathrm{ppb}$ in 2008 , and
$4.7 \pm 0.6 \mathrm{ppb}$ in 2009 (Dlugokencky et al., 2011), our updated result proves that the renewed methane increase meanwhile has been persisting for $>5$ years [mid 2006, Sep 2011]. This is either the longest and largest positive trend anomaly since the beginning of systematic observations more than 25 years ago or the onset of a new period of strongly increasing $\mathrm{CH}_{4}$ levels in the atmosphere. Several scenarios have been developed to explain the persistent increase observed, mainly invoking an increase in emissions from natural wetlands, an increase in fossil fuel-related emissions or a decrease in $\mathrm{OH}$ concentrations. However, more work is needed to fully attribute this increase to a particular source or sink.

\section{Introduction}

The molecular symmetry of methane $\left(\mathrm{CH}_{4}\right)$ allows for highly active vibration-rotation excitation by infrared absorption. Carbon dioxide $\left(\mathrm{CO}_{2}\right)$ is also infrared-active, however, its strongest absorption lines are located outside the atmospheric window. These are basic reasons why methane is the second important anthropogenic greenhouse gas in spite of its still relatively small abundance in the atmosphere.

Methane concentrations in the atmosphere have more than doubled since the beginning of industrialization (Forster et al., 2007). After a period of near-zero growth at the beginning of this century (Dlugokencky et al., 2003; Bousquet et al., 2006), the growth rate of atmospheric methane started to increase strongly again after 2006 (Rigby et al., 2008; Dlugokencky et al., 2009). The attribution of this increase to a particular source or sink is still debated in the scientific 
community (Rigby et al., 2008; Dlugokencky et al., 2009; EDGAR, 2012; Bloom et al., 2010; Ringeval et al., 2010; Aydin et al., 2011; Bousquet et al., 2011; Spahni et al., 2011).

The finding of an atmospheric increase since 2007 is based on highly precise measurements $(\approx 0.2 \%)$ of the methane mixing ratio by atmospheric networks at the surface and in the planetary boundary layer (WMO, 2012). Satellite retrievals (Crevoisier et al., 2009; Frankenberg et al., 2011; Schneising et al., 2011, 2012) complement these surface observations with a higher spatial coverage, but at the cost of lower precisions $(\approx 2 \%)$. Several studies have focused on how column observations can complement surface networks and help further reduce uncertainties associated with sources and sinks in atmospheric inversions (e.g., Olsen and Randerson, 2004 or Bergamaschi et al., 2009, and references therein). Columnar methane retrieved from ground-based Fourier-transform-infrared (FTIR) spectrometry in the midinfrared (mid-IR) provides a column view of atmospheric methane at a high precision close to that attainable by surface networks $(\approx 0.3 \%$, Sussmann et al., 2011). Hence such ground-based observations are very useful to document atmospheric methane changes. In this paper, we investigate the persistence of the 2007-2008 anomaly by an updated trend analysis including FTIR data until today (fall 2011) and report possible causes of the increase observed.

After describing the mid-IR sounding technique (Sect. 2), methane time series and trends will be presented in Sect. 3.1, and the trends from the neighboring sites of Zugspitze and Garmisch will be compared to each other as well as to SCIAMACHY trends derived with the same analysis method (Sect. 3.2). Section 4 will provide a discussion of the trend behavior derived for the 2007-2011 time period along with some conclusions.

\section{Sounding technique}

Time series of column-averaged dry-air mole fractions of methane $\left(\mathrm{XCH}_{4}\right)$ were retrieved from long-term FTIR solar absorption measurements at two northern mid-latitude sites, namely, the Zugspitze high-altitude site $\left(47.42^{\circ} \mathrm{N}\right.$, $10.98^{\circ} \mathrm{E}, 2964 \mathrm{~m}$ a.s.1.) and Garmisch $\left(47.48^{\circ} \mathrm{N}, 11.06^{\circ} \mathrm{E}\right.$, $743 \mathrm{~m}$ a.s.l.). The two sites are located only a few kilometers apart in horizontal distance. However, the levels of integrated water vapor differ strongly $(\min / \mathrm{max}=0.2 \mathrm{~mm} / 12.7 \mathrm{~mm}$ for Zugspitze, $1.9 \mathrm{~mm} / 34.9 \mathrm{~mm}$ for Garmisch) because of the altitude difference.

The Zugspitze FTIR system has been conducting continuous measurements since 1995 as part of the Network for the Detection of Atmospheric Composition Change (NDACC, http://www.ndacc.org). It is operated by the Group "Variability and Trends" of IMK-IFU ${ }^{1}$, Karlsruhe Institute of Tech-

\footnotetext{
${ }^{1}$ Institute of Meteorology and Climate Research - Atmospheric Environmental Research, http://www.imk-ifu.kit.edu/atmospheric_ variability.php
}

nology, at the Zugspitze ${ }^{2}$. The FTIR system is based on a Bruker IFS125HR interferometer; details can be found in Sussmann and Schäfer (1997). The interferograms for the methane retrievals were recorded with an InSb detector using an optical path difference of typically $175 \mathrm{~cm}$. 6 scans were averaged $(\approx 7$-min integration time). The pressure-temperature profiles necessary for the inversion were taken from the National Center for Environmental Prediction (NCEP) automailer. The Garmisch solar FTIR system was set up in 2004 at the Garmisch site ${ }^{3}$ and is part of the Total Carbon Column Observing Network (TCCON, http://www.tccon.caltech.edu/) operating in the near-infrared for high-precision retrieval of column-averaged mixing ratios of carbon dioxide and methane. The system performs mid-IR NDACC-type measurements in parallel (in alternating mode on the time scale of several minutes). The latter are utilized for this study. The measurement settings for the Garmisch mid-IR methane measurements are the same as for the Zugspitze.

Retrievals of columnar methane from ground-based FTIR spectrometry in the mid-IR were used previously for trend studies (Zander et al., 1989; Angelbratt et al., 2011) and satellite validation (e.g., Sussmann et al., 2005). However, it became obvious only recently that the methane-column retrievals at high-humidity (low-altitude) sites may be dominated by water vapor $\left(\mathrm{H}_{2} \mathrm{O} / \mathrm{HDO}\right)-\mathrm{CH}_{4}$ interference errors of up to 5\% (Sussmann et al., 2011). Consequently, artifacts dominated the seasonal cycle of methane retrieved with the standard NDACC retrieval strategy. Dry (highaltitude) sites were not affected. Note that water vapor interference also perturbed methane retrievals from SCIAMACHY (Frankenberg et al., 2008). A general formulation of the (water vapor) interference problem was given before (Sussmann and Borsdorff, 2007) and water vapor can be quantified by the FTIR technique itself (e.g., Sussmann et al., 2009). To improve the standard methane retrieval strategy used within NDACC, we recently developed a new retrieval strategy (MIR-GBM v1.0) using systematically selected spectral micro windows and spectroscopic parameters (Sussmann et al., 2011). MIR-GBM v1.0 was shown to eliminate $\mathrm{H}_{2} \mathrm{O} / \mathrm{HDO}-\mathrm{CH}_{4}$ interference errors down to the $\approx 0.1 \%$ level (i.e., $0.14 \%$ for the wettest test site and $0.10 \%$ and $0.02 \%$, respectively, for the two dryer test sites). For the first time, a good agreement of the retrieved northernhemisphere seasonal cycle with SCIAMACHY results was achieved (Sussmann et al., 2011).

In this paper we apply MIR-GBM v1.0 to a trend analysis. The basic features of this retrieval strategy are given in Table 1, more details can be found in Sussmann et al. (2011).

\footnotetext{
${ }^{2}$ Zugspitze site details can be found at http://www.imk-ifu.kit. edu/311.php

${ }^{3}$ Garmisch site details can be found at http://www.imk-ifu.kit. edu/315.php
} 
Table 1. Characteristics of the strategy for retrieval of column-averaged methane from mid-IR solar spectra (MIR-GBM v1.0). For more details, see Sussmann et al. (2011).

\begin{tabular}{|c|c|}
\hline micro windows (interfering species fitted) & $\begin{array}{l}2613.70-2615.40\left(\mathrm{HDO}, \mathrm{CO}_{2}\right) \\
2835.50-2835.80(\mathrm{HDO}) \\
2921.00-2921.60\left(\mathrm{HDO}, \mathrm{H}_{2} \mathrm{O}, \mathrm{NO}_{2}\right)\end{array}$ \\
\hline line list & HITRAN 2000, including 2001 update release \\
\hline $\begin{array}{l}\text { retrieval constraint } \\
\text { regularization strength } \alpha\end{array}$ & $\begin{array}{l}\text { Tikhonov } \mathrm{L}_{1} \\
\text { optimized via } \mathrm{L} \text {-curve/minimum diurnal } \\
\text { variation }\left(\mathrm{dofs}^{\mathrm{a}} \approx 2\right)\end{array}$ \\
\hline altitude dependency of reg. strength & altitude constant on per-cent-vmr ${ }^{b}$ scale \\
\hline a priori vmr profiles & WACCM $^{\mathrm{c}}$ \\
\hline background fit & linear slope \\
\hline retrieval quality selection & threshold $(0.15 \%)$ for rms-noise/dofs \\
\hline $\begin{array}{l}\text { calculation of column-averaged dry-air } \\
\text { mole fractions }\end{array}$ & $\begin{array}{l}\text { use 4-times-daily-NCEP }{ }^{\mathrm{d}} \text { PTU profiles, } \\
\text { interpolate to FTIR measurement time, } \\
\text { calculate air column, } \\
\text { subtract water vapor column }\end{array}$ \\
\hline precision $(1-\sigma \text { diurnal variation })^{\mathrm{e}}$ & $<0.3 \%$ \\
\hline $\begin{array}{l}\text { seasonal bias }\left(\mathrm{H}_{2} \mathrm{O} / \mathrm{HDO}-\mathrm{CH}_{4}\right. \\
\text { interferenceerror) }\end{array}$ & $<0.14 \%$ \\
\hline $\begin{array}{l}\text { dofs }-d \text { egrees of } f \text { reedom } f \text { or } \text { signal } \\
\text { vmr - volume } m \text { ixing } r \text { atio } \\
\text { WACCM - Whole Atmosphere Chemistry Climate } M \text { odel } \\
\text { NCEP }-N \text { ational } C \text { enter for Environmental Prediction } \\
\text { for } 7 \text {-min integration }\end{array}$ & \\
\hline
\end{tabular}

\section{Trend results}

\subsection{Time series and trend analysis}

Figure 1a shows the time series of monthly-mean columnaveraged methane above Zugspitze and Garmisch. Typically, $n=40-60$ individual column measurements per month are recorded on 6-8 clear sky days. Shaded bars in Fig.1a indicate the statistical uncertainties of the monthly means calculated from the individual measurements $( \pm 3 \sigma / \operatorname{sqrt}(n))$. These suggest that statistically stable monthly means are obtained for the trend analysis.

The de-seasonalized time series (Fig. 1b) shows a significant increase during the 3-years' time interval [1996, 1998], followed by a period with no significant growth [1999, mid 2006]. Afterwards, a renewed strong increase can be observed, which has been persisting for 5 years now [mid 2006, Sep 2011]. The division into 3 time periods is in agreement with dedicated trend change points defined and used for methane in earlier work (Dlugokencky et al., 2003, 2009; Angelbratt et al., 2011). Our trend analysis is based on the approach described in Gardiner et al. (2008). See Table 2 for the resulting figures. Briefly, the approach augments a basic linear trend model applied to the indicated parts of the time series after subtraction of a fitted intra-annual function and uses least squares regression in conjunction with a boot- strap resampling of the residuals in order to determine confidence limits associated with the trend estimates. For the intra-annual model, a 3rd-order Fourier series is used.

As a main result from Table 2, the original anomaly of the period [mid 2006, 2008] with a Zugspitze trend of $6.6[3.5,9.8] \mathrm{ppb} \mathrm{yr}^{-1}$ and a Garmisch trend of $5.1[2.0$,

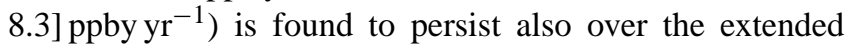
period [mid 2006, Sep 2011] investigated now (Zugspitze trend $4.8[3.8,5.9] \mathrm{ppbyr}^{-1}$, Garmisch trend $5.1[4.2$, $6.0] \mathrm{ppb} \mathrm{yr}^{-1}$ ).

\subsection{Station-to-station consistency and comparison to SCIAMACHY trends}

The FTIR trends retrieved for the neighboring sites of Zugspitze and Garmisch (Table 2) are in very good agreement: For the [mid 2006-2008] period, a trend of $6.6 \mathrm{ppbyr}^{-1}$ with a $95 \%$ confidence interval of [3.5, 9.8] $\mathrm{ppbyr}^{-1}$ is found above Zugspitze, which agrees with $5.1[2.0,8.3] \mathrm{ppb} \mathrm{yr}^{-1}$ retrieved from Garmisch measurements for the same period. For the [mid 2006-Sep 2011] period, the trend of $4.8[3.8,5.9] \mathrm{ppb} \mathrm{yr}^{-1}$ above Zugspitze is close to the Garmisch trend of $5.1[4.2,6.0] \mathrm{ppb} \mathrm{yr}^{-1}$. These numbers indicate a very good station-to-station consistency of the ground-based FTIR trend results. 
Table 2. Existence and significance of trends of column-averaged mole fractions of $\mathrm{CH}_{4}$.

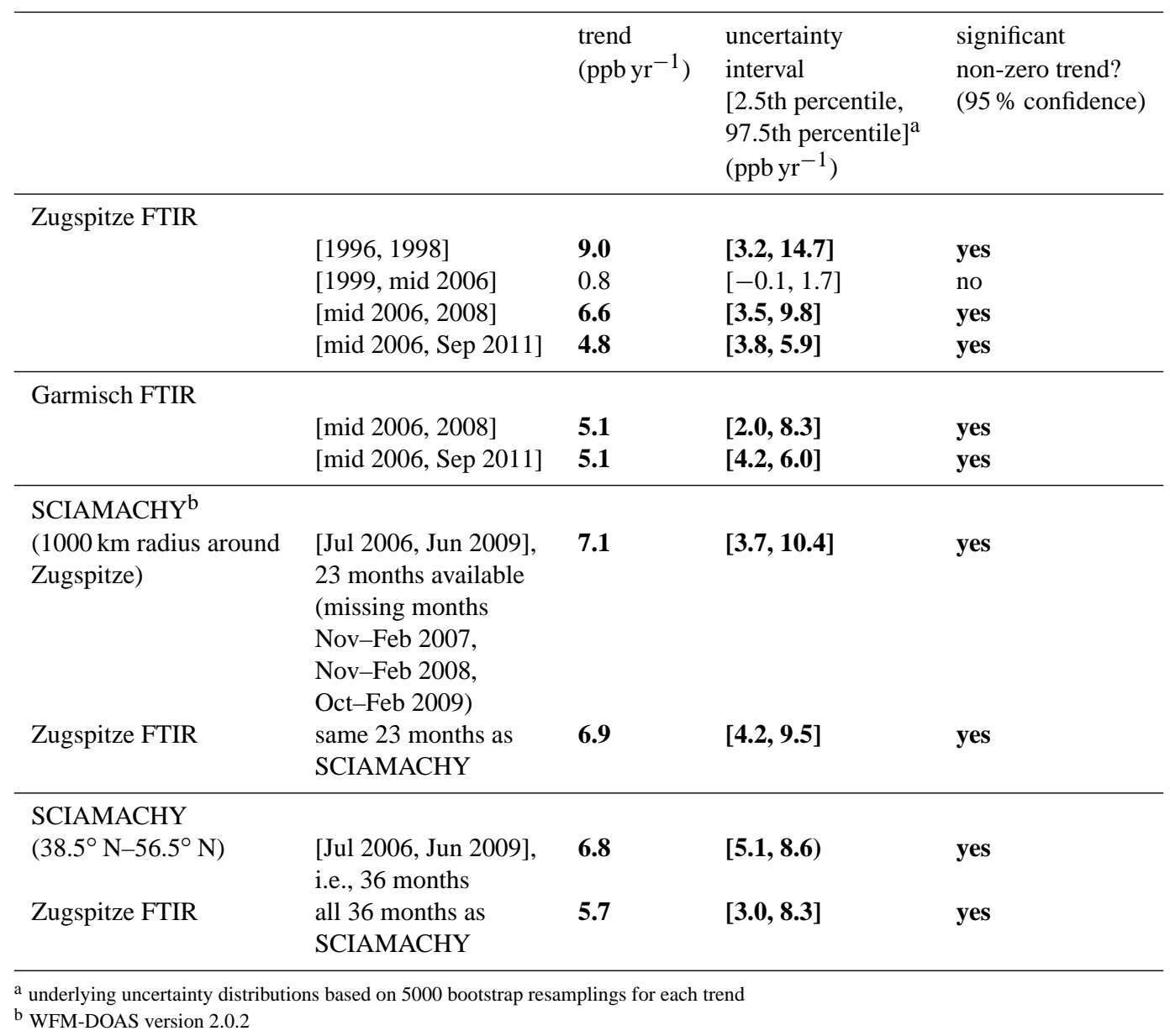

The trend of $6.6[3.5,9.8] \mathrm{ppb} \mathrm{yr}^{-1}$ derived from our Zugspitze time series for the period [mid 2006, 2008] agrees qualitatively with earlier studies using in-situ data for both hemispheres, according to which the growth rate of atmospheric methane started to increase after 2006 with changes of $8.0 \pm 0.6 \mathrm{ppb}$ in $2007,6.4 \pm 0.6 \mathrm{ppb}$ in 2008 , and $4.7 \pm 0.6 \mathrm{ppb}$ in 2009 (Dlugokencky et al., 2011).

For a quantitative validation of the FTIR trend results, a dedicated intercomparison with SCIAMACHY retrievals of column-averaged mole fractions using the WFM-DOAS algorithm version 2.02 (Schneising et al., 2011) was made, see Table 2. The trend intercomparison was performed for the time interval [Jul 2006, Jun 2009]. For a 1000-km pixel selection radius around the Zugspitze, the SCIAMACHY $\mathrm{XCH}_{4}$ data available cover 23 months (typically, the fallwinter months November to February are missing). For these SCIAMACHY data, the trend and its $95 \%$ confidence interval were analyzed with the same (bootstrap) technique as described for the FTIR trend analysis above. The resulting SCIAMACHY trend is $7.1[3.7,10.4] \mathrm{ppb} \mathrm{yr}^{-1}$, see Table 2. For the same 23 months, an FTIR trend of 6.9 [4.2, 9.5] $\mathrm{ppb} \mathrm{yr}^{-1}$ is obtained. Both trends agree within the error bars. The FTIR uncertainty interval is narrower than that of SCIAMACHY.

Using a full latitudinal band of $\approx 1000 \mathrm{~km}$ half-width centered around the Zugspitze latitude (i.e., covering $38.5^{\circ} \mathrm{N}-$ $56.5^{\circ} \mathrm{N}$ ), we obtained a SCIAMACHY trend of 6.8 [5.1, 8.6] $\mathrm{ppb} \mathrm{yr}^{-1}$ (Table 2). Note that due to the loosened spatial selection (full latitudinal band), SCIAMACHY retrievals become available for all 36 months of the 3-years' time interval. For the same 36 months, we derived an FTIR trend

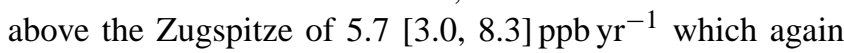
agrees to the SCIAMACHY trend. As more SCIAMACHY data are applied in the trend analysis in this case, the SCIAMACHY confidence interval is narrower than the FTIR confidence (Table 2). Overall, the $\mathrm{XCH}_{4}$ trends derived from ground-based FTIR and SCIAMACHY are in good agreement.

\section{Discussion and conclusion}

The methane increase persisting for 5 years [mid 2006, Sep 2011] as documented in Fig. 1 and Table 2 is either the 


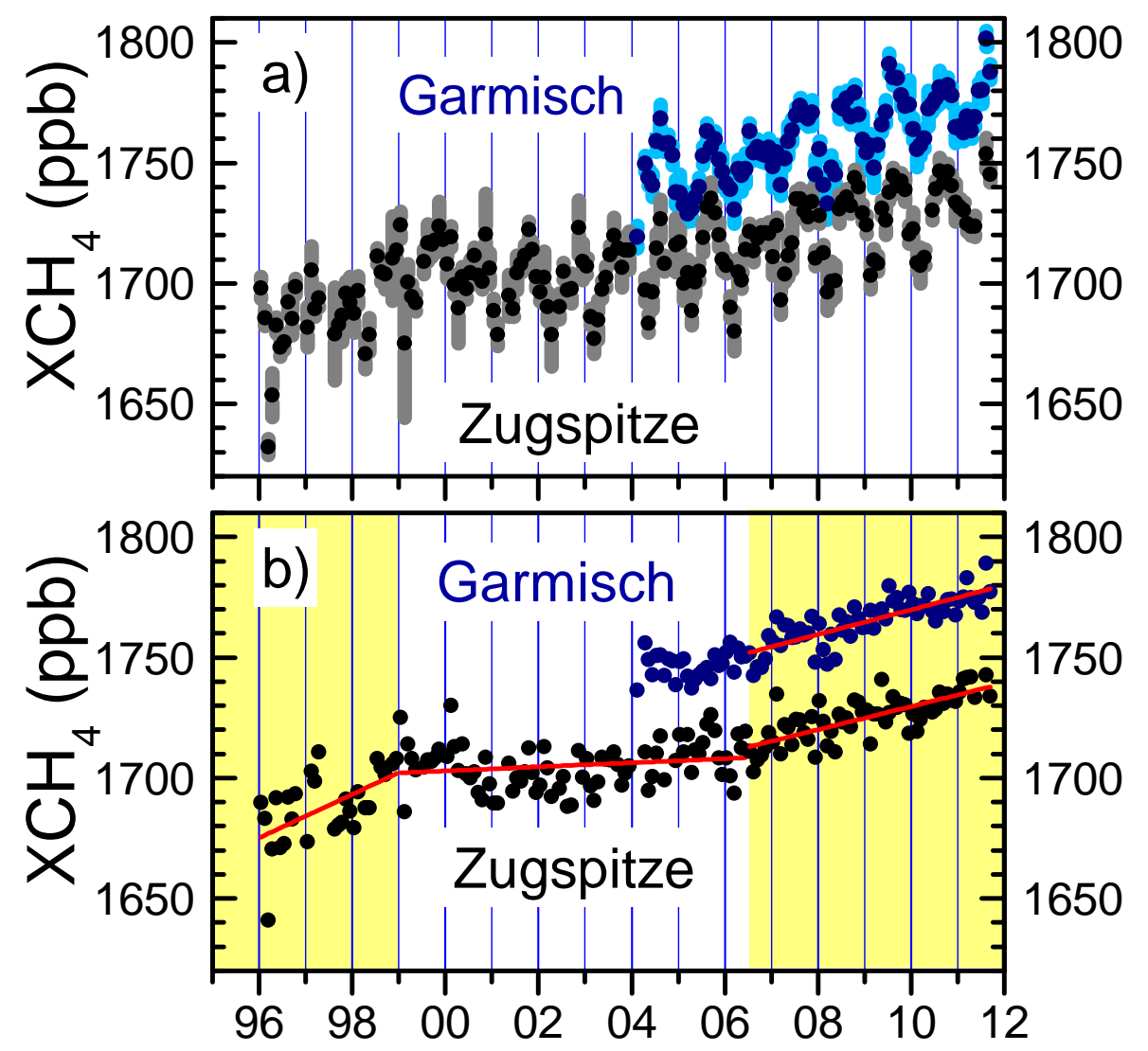

Fig. 1. (a) Time series of methane column-averaged mole fractions above Zugspitze and Garmisch (monthly means). Shaded bars indicate the statistical error of the monthly means calculated from the individual measurements $( \pm 3 \sigma / \operatorname{sqrt}(n))$, where $n$ is the number of FTIR measurements per month. (b) De-seasonalized time series and linear trends (red lines). See Table 2 for trend magnitudes and significance.

longest and largest positive trend anomaly since the beginning of systematic observations more than 25 years ago or marks the onset of a new period of strongly increasing $\mathrm{CH}_{4}$ levels in the atmosphere. Our study cannot identify the mechanisms behind this increase, but our findings shall be discussed briefly in relation to previous studies on this subject and most reasonable causes shall be proposed.

Previous studies discussed possible causes of the increase in the years 2007 and 2008 (Rigby et al., 2008; Duglokencky et al., 2009; Bloom et al., 2010; van der Werf et al., 2010; Bousquet et al., 2011; Frankenberg et al., 2011; Spahni et al., 2011; Montzka et al., 2011). On the source side, a positive anomaly of $\mathrm{CH}_{4}$ emissions from natural wetlands in 2007-2008 is suggested to be the cause by several authors (Duglokencky et al., 2009; Bloom et al., 2010; Bousquet et al., 2011), with the contribution from boreal regions in 2007 being estimated to amount about $25 \%$ (Bousquet et al., 2011). Indeed, Siberia experienced high abnormally positive temperatures in autumn $\left(+4{ }^{\circ} \mathrm{C}\right.$ compared to the $1961-$ 1990 mean, National Climatic Data Center, Dlugokencky et al., 2009). The remaining $75 \%$ are mostly attributed to tropical natural wetlands. Tropical areas which include large wet- land surface areas on a global scale experienced the 3rdlargest (2007) and the largest (2008) positive precipitation anomalies from 1986 to 2008 (Schneider et al., 2008; Dlugokencky et al., 2009). These findings are supported by the emission increase computed by two process-based models for natural wetlands (Ringeval et al., 2011; Spahni et al., 2011) because of tropical precipitation changes associated with the La Niña event in these years and because of boreal positive temperature anomalies in 2007 . These findings are also consistent with processes relating to hydrology being the dominant driver of wetland $\mathrm{CH}_{4}$ emissions in the tropics, whereas temperature is more important at high latitudes (Walter et al., 2001; Ringeval et al., 2010). According to economic statistics, the EDGAR inventory for anthropogenic emissions (EDGAR, 2012) reveals a large increase of fossil fuel emissions after 2000, mainly due to Asian regions, of $+6-7 \mathrm{Tg} \mathrm{yr}^{-1}$. This finding is supported neither by a recent atmospheric inversion (Bousquet et al., 2011) nor by a study based on ethane trends (Aydin et al., 2011). In addition, the biomass burning contribution is insignificant, because no large CO anomaly is observed in 2007-2008 (van der Werf et al., 2010). 
On the sink side, Rigby et al. (2008) and Montzka et al. (2011) find a generally declining $\mathrm{OH}$ concentration between 2004 and 2007, which might have contributed to the enhanced $\mathrm{CH}_{4}$ in the atmosphere. However, the large, although uncertain, $4 \pm 14 \%$ drop between 2006 and 2007 inferred by Rigby is much larger than the small drop found by Montzka using several modeling approaches $(\sim 1 \% / \mathrm{yr})$. Small inter-annual variability of $\mathrm{OH}$ concentrations is in better agreement with the results of most climate chemistry models which largely buffer $\mathrm{OH}$ changes (Dentener et al., 2003). Having in mind that methane loss by $\mathrm{OH}$ radicals is proportional to the product of $\mathrm{OH}$ concentrations by the $\mathrm{CH}_{4}$ mixing ratio, even a decrease of $\mathrm{OH}$ concentration does not guarantee a decreased loss of methane by $\mathrm{OH}$ radicals. $\mathrm{CH}_{4}$ has increased by about $0.3 \%$ /yr since 2007 , which may, at least partly, compensate the impact of the potentially decreasing $\mathrm{OH}$ concentrations on $\mathrm{CH}_{4}$ mixing ratios.

Attribution of the persistent increase to a particular source or sink after 2009 still is under investigation. On the one hand, a persisting natural wetland anomaly over more than a few years may be in conflict with the understanding that wetland emissions typically cause inter-annual variability (i.e., 1-2 yr time scale), except for long-term precipitation or temperature anomalies. On the other hand, more gradual changes on the time scale of several years would be explained more consistently by changing anthropogenic emissions.

Finally, no evidence of strongly increased emissions from stores of carbon in melting permafrost and from marine hydrates as a reaction to climate change can be found today from atmospheric observations. However, both will remain potential sources of severely increasing methane emissions in the future, which should be monitored closely by remote sensing at the surface or from space.

Acknowledgements. We thank H. P. Schmid (IMK-IFU) for his continuous interest in this work. It is a pleasure to acknowledge valuable input from both anonymous referees which helped to significantly improve the paper. The authors are indebted to O. Schneising and J. P. Burrows (IEP Bremen) for providing SCIAMACHY data. Earlier studies which contributed to this paper were funded by the EC within the HYMN project (contract 037048). We acknowledge support by the ESA GHG-cci project under a subcontract with the University of Bremen as well as by the Deutsche Forschungsgemeinschaft and Open Access Publishing Fund of Karlsruhe Institute of Technology.

Edited by: I. Aben

\section{References}

Angelbratt, J., Mellqvist, J., Blumenstock, T., Borsdorff, T., Brohede, S., Duchatelet, P., Forster, F., Hase, F., Mahieu, E., Murtagh, D., Petersen, A. K., Schneider, M., Sussmann, R., and Urban, J.: A new method to detect long term trends of methane $\left(\mathrm{CH}_{4}\right)$ and nitrous oxide $\left(\mathrm{N}_{2} \mathrm{O}\right)$ total columns measured within the NDACC ground-based high resolution solar FTIR network, Atmos. Chem. Phys., 11, 6167-6183, doi:10.5194/acp-11-61672011, 2011.

Aydin, M., Verhulst, K. R., Saltzman, E. S., Battle, M. O., Montzka, S. A., Blake, D. R., Tang, Q., and Prather, M. J.: Recent decreases in fossil-fuel emissions of ethane and methane derived from firn air, Nature, 476, 198-201, 2011.

Bergamaschi, P, Frankenberg, C., Meirink, J.F., Krol, M, Villani, M. G., Houweling, S., Dentener, F., Dlugokencky, E.J., Miller, J.B., Gatti, L.V., Engel, A., and Levin, I.: Inverse modeling of global and regional $\mathrm{CH} 4$ emissions using SCIAMACHY satellite retrievals, J. Geophys. Res., 114, D22301, doi:10.1029/2009JD012287, 2009.

Bloom, A. A., Palmer, P. I., Fraser, A., Reay, D. S., and Frankenberg, C.: Large-Scale Controls of Methanogenesis Inferred from Methane and Gravity Spaceborne Data, Science, 327, 322-325, doi:10.1126/science.1175176, 2010.

Bousquet, P., Ciais, P., Miller, J. B., Dlugokencky, E. J., Hauglustaine, D. A., Prigent, C., Van der Werf, G. R., Peylin, P., Brunke, E. G., Carouge, C., Langenfels, R. L., Lathiere, J., Papa, F., Ramonet, M., Schmidt, M., Steele, L. P., Tyler, S. C., and White, J.: Contribution of anthropogenic and natural sources to atmospheric methane variability, Nature, 443, 439-443, 2006.

Bousquet, P., Ringeval, B., Pison, I., Dlugokencky, E. J., Brunke, E.G., Carouge, C., Chevallier, F., Fortems-Cheiney, A., Frankenberg, C., Hauglustaine, D. A., Krummel, P. B., Langenfelds, R. L., Ramonet, M., Schmidt, M., Steele, L. P., Szopa, S., Yver, C., Viovy, N., and Ciais, P.: Source attribution of the changes in atmospheric methane for 2006-2008, Atmos. Chem. Phys., 11, 3689-3700, doi:10.5194/acp-11-3689-2011, 2011.

Crevoisier, C., Nobileau, D., Fiore, A. M., Armante, R., Chédin, A., and Scott, N. A.: Tropospheric methane in the tropics - first year from IASI hyperspectral infrared observations, Atmos. Chem. Phys., 9, 6337-6350, doi:10.5194/acp-9-6337-2009, 2009.

Dentener, F., Peters, W., Krol, M., van Weele, M., Bergamaschi, P., and Lelieveld, J.: Inter-annual variability and trend of $\mathrm{CH}_{4}$ lifetime as a measure for $\mathrm{OH}$ changes in the 1979-1993 time period, J. Geophys. Res.-A, 108, 4442, doi:10.1029/2002JD002916, 2003.

Dlugokencky, E. J., Houweling, S., Bruhwiler, L., Masarie, K. A., Lang, P. M., Miller, J. B., and Tans, P. P.: Atmospheric methane levels off: Temporary pause or a new steady-state?, Geophys. Res. Lett., 30, 1992, doi:10.1029/2003GL018126, 2003.

Dlugokencky, E. J., Bruhwiler, L., White, J. W. C., Emmons, L. K., Novelli, P. C., Montzka, S. A., Masarie, K. A., Lang, P. M., Crotwell, A. M., Miller, J. B., and Gatti, L. V.: Observational constraints on recent increases in the atmospheric $\mathrm{CH}_{4}$ burden, Geophys. Res. Lett., 36, L18803, doi:10.1029/2009GL039780, 2009.

Dlugokencky, E. J., Nisbet, E. G., Fisher, R., and Lowry, D.: Global atmospheric methane: budget, changes and dangers, Phil. Trans. R. Soc. A, 369, 2058-2072, doi:10.1098/rsta.2010.0341, 2011. 
EDGAR4 database: Emission Database for Global Atmospheric Research (EDGAR), release version 4.2, http://edgar.jrc.ec. europa.eu, European Commission, Joint Research Centre (JRC)/Netherlands Environmental Assessment Agency (PBL), 2012.

Forster, P., Ramaswamy, V., Artaxo, P., Berntsen, T., Betts, R., Fahey, D., Haywood, J., Lean, J., Lowe, D., Myhre, G., Nganga, J., R. Prinn, G. Raga, M. S., and Dorland, R. V.: Changes in Atmospheric Constituents and in Radiative Forcing, Climate Change 2007: The Physical Science Basis. Contribution of Working Group I to the Fourth Assessment Report of the Intergovernmental Panel on Climate Change (IPCC), 2007.

Frankenberg, C, Bergamaschi, P., Butz, A., Houweling, S., Meirink, J.F., Notholt, J., Petersen, A.K., Schrijver, H., Warneke, T., and Aben, I.: Tropical methane emissions: A revised view from SCIAMACHY onboard ENVISAT, Geophys. Res. Lett., 35, L15811, doi:10.1029/2008GL034300, 2008.

Frankenberg, C., Aben, I., Bergamaschi, P., Dlugokencky, E.J., van Hees, R., Houweling, S., van der Meer, P., Snel, R., and Tol, P.: Global column-averaged methane mixing ratios from 2003 to 2009 as derived from SCIAMACHY: Trends and variability, J. Geophys. Res., 116, D04302, doi:10.1029/2010JD014849, 2011.

Gardiner, T., Forbes, A., de Mazière, M., Vigouroux, C., Mahieu, E., Demoulin, P., Velazco, V., Notholt, J., Blumenstock, T., Hase, F., Kramer, I., Sussmann, R., Stremme, W., Mellqvist, J., Strandberg, A., Ellingsen, K., and Gauss, M.: Trend analysis of greenhouse gases over Europe measured by a network of ground-based remote FTIR instruments, Atmos. Chem. Phys., 8, 6719-6727, doi:10.5194/acp-8-6719-2008, 2008.

Montzka, S. A., Krol, M., Dlugokencky, E., Hall, B., Jockel, P., and Lelieveld, J.: Small Interannual Variability of Global Atmospheric Hydroxyl, Science, 331, 67-69, doi:10.1126/science.1197640, 2011.

Olsen, S. C. and Randerson, J. T.: Differences between surface and column atmospheric $\mathrm{CO}_{2}$ and implications for carbon cycle research, J. Geophys. Res., 109, D02301, 2004, doi:10.1029/2003JD003968.

Rigby, M., Prinn, R. G., Fraser, P. J. Simmonds, P. G., Langenfelds, R. L., Huang, J., Cunnold, D. M., Steele, L. P., Krummel, P. B., Weiss, R. F., O'Doherty, S., Salameh, P. K., Wang, H. J., Harth, C. M., Mühle, J., and Porter, L. W.: Renewed growth of atmospheric methane, Geophys. Res. Lett., 35, L22805, doi:10.1029/2008GL036037, 2008.

Ringeval, B., de Noblet-Ducoudre, N., Ciais, P., Bousquet, P., Prigent, C., Papa, F., and Rossow, W. B.: An attempt to quantify the impact of changes in wetland extent on methane emissions on the seasonal and interannual time scales, Global Biogeochem. Cy., 24, Gb2003, doi:10.1029/2008GB003354, 2010.

Schneider, U., Fuchs, T., Meyer-Christoffer, A., and Rudolf, B.: Global precipitation analysis products of the GPCC, Global Precip. Climatol. Cent., Dtsch. Wetterdienst, Offenbach am Main, Germany, 2008.

Schneising, O., Buchwitz, M., Reuter, M., Heymann, J., Bovensmann, H., and Burrows, J. P.: Long-term analysis of carbon dioxide and methane column-averaged mole fractions retrieved from SCIAMACHY, Atmos. Chem. Phys., 11, 28632880, doi:10.5194/acp-11-2863-2011, 2011.
Schneising, O., Bergamaschi, P., Bovensmann, H., Buchwitz, M., Burrows, J. P., Deutscher, N. M., Griffith, D. W. T., Heymann, J., Macatangay, R., Messerschmidt, J., Notholt, J., Rettinger, M., Reuter, M., Sussmann, R., Velazco, V. A., Warneke, T., Wennberg, P. O., and Wunch, D.: Atmospheric greenhouse gases retrieved from SCIAMACHY: comparison to ground-based FTS measurements and model results, Atmos. Chem. Phys., 12, 1527-1540, doi:10.5194/acp-12-1527-2012, 2012.

Spahni, R., Wania, R., Neef, L., van Weele, M., Pison, I., Bousquet, P., Frankenberg, C., Foster, P.N., Joos, F., Prentice, I.C., and van Velthoven, P.: Constraining global methane emissions and uptake by ecosystems, Biogeosciences, 8., 643-1665, 2011.

Sussmann, R. and Borsdorff, T.: Technical Note: Interference errors in infrared remote sounding of the atmosphere, Atmos. Chem. Phys., 7, 3537-3557, doi:10.5194/acp-7-3537-2007, 2007.

Sussmann, R. and Schäfer, K.: Infrared spectroscopy of tropospheric trace gases: combined analysis of horizontal and vertical column abundances, Appl. Opt., 36, 735-741, 1997.

Sussmann, R., Stremme, W., Buchwitz, M., and de Beek, R.: Validation of ENVISAT/SCIAMACHY columnar methane by solar FTIR spectrometry at the Ground-Truthing Station Zugspitze, Atmos. Chem. Phys., 5, 2419-2429, doi:10.5194/acp-5-24192005, 2005.

Sussmann, R., Borsdorff, T., Rettinger, M., Camy-Peyret, C., Demoulin, P., Duchatelet, P., Mahieu, E., and Servais, C.: Technical Note: Harmonized retrieval of column-integrated atmospheric water vapor from the FTIR network - first examples for longterm records and station trends, Atmos. Chem. Phys., 9, 89878999, doi:10.5194/acp-9-8987-2009, 2009.

Sussmann, R., Forster, F., Rettinger, M., and Jones, N.: Strategy for high-accuracy-and-precision retrieval of atmospheric methane from the mid-infrared FTIR network, Atmos. Meas. Tech., 4, 1943-1964, doi:10.5194/amt-4-1943-2011, 2011.

van der Werf, G. R., Randerson, J. T., Giglio, L., Collatz, G. J., Mu, M., Kasibhatla, P. S., Morton, D. C., DeFries, R. S., Jin, Y., and van Leeuwen, T. T.: Global fire emissions and the contribution of deforestation, savanna, forest, agricultural, and peat fires (19972009), Atmos. Chem. Phys., 10, 11707-11735, doi:10.5194/acp10-11707-2010, 2010.

Walter, B. P., Heimann, M., and Matthews, E.: Modeling modern methane emissions from natural wetlands: 2. Interannual variations 1982-1993, J. Geophys. Res., 106, 34207-34219, doi:10.1029/2001JD900164, 2001.

WMO World Data Centre for Greenhouse Gases: http://ds.data.jma. go.jp/gmd/wdcgg/introduction.html, last access: 31 March 2012, 2012.

Zander, R., Demoulin, Ph., Ehhalt, D. H., and Schmidt, U.: Secular Increase of the Vertical Column Abundance of Methane Derived from IR Solar Spectra Recorded at the Jungfraujoch Station, J. Geophys. Res., 94, 11029-11039, 1989. 